\title{
Strategy For Implementing Online Learning In Bengkulu
}

\author{
'Sumarsih \\ IUniversity of Bengkulu, Bengkulu, Indonesia \\ 1*sumarsihasiih@gmail.com
}

\begin{tabular}{l}
\hline Info \\
\hline Article history \\
Accepted January 28, 2022 \\
Revised January 29, 2022 \\
Accepted January 31, 2022 \\
\hline
\end{tabular}

Keywords: Online Learning, Strategy, implementation of the program

\begin{abstract}
The purpose of this study was to describe the strategy for implementing online learning at Public vocational secondary schools Bengkulu Utara Regency. This research is a qualitative descriptive study. The research subjects were the principal, teachers, and students. Data collection techniques using interviews and documentation. The results showed that online learning strategies were implemented using a variety of methods between meetings using zoom meetings, video calls. giving assignments via WhatsApp, PowerPoint, youtube, and giving weekly assignments. While the obstacles lack of motivation to learn, lack of discipline in doing assignments, lack of understanding of the material, high parental credit costs, internet network disruption. Solutions made by schools increase teacher knowledge through training, teacher group discussion forums.
\end{abstract}

\section{INTRODUCTION}

The Covid-19 pandemic that is currently sweeping the world, including Indonesia, has an impact on the delivery of education in schools. The learning system can no longer be implemented face-to-face in the classroom as usual, so schools need to change learning patterns massively due to social distancing. The learning process that should have been carried out face-to-face has now turned into a distance learning system or online. United Nations organization in charge of education, science, and culture UNESCO said that more than 850 million students in the world cannot study in school due to this virus, including in Indonesia. (Fauzi \& Khusuma,2020), (Priyadarshini \& Bhaumik,2020).

The government through the Minister of Education and Culture issued Circular Number 36962 /MPK. A /HK /2020 concerning Online Learning and Working from Home to Prevent the Spread of Covid-19, stating that all teaching and learning activities both at schools and college campuses use the online method as an effort to prevent the development and spread of Coronavirus disease. This condition suddenly causes many schools to move quickly to prepare learning according to the abilities of their respective schools. Online media is considered very effective as a rarity. Teachers only need to provide questions which will be sent via cellphones/laptops of students or parents. Then the students just need to do the assignments from the teacher. (Watson, 2008), The results of the work or assignments are sent back to the teacher via whats App the application or collected at school. Distance learning 
policies with online media, either using a cellphone, computer or laptop. The solution to prevent the spread of Covid-19 in an educational setting. (Priyadarshini, \& Bhaumik, R, 2020). (Samruayruen, et al, 2013).

The results of the study Hikmah Mu'alimah dan Ishafit (2017), state that the online collaborative inquiry learning method with Whats App social media can be used as a learning medium in the 21st century. As Eko Kuntarto's research results (2017), the online learning model has been able to increase student absorption of lectures. This is by the characteristics of online learning (Allan J. Henderson, 2003), (Yudiawan \& Sunarso, 2021)., which allows students to learn without having to go to the classroom, and learning can be scheduled according to the agreement between the instructor and students, or students can determine their own learning time. which are desired. (Kaler, 2012), (Sadiq, 2020).

Apart from some of the above advantages, online learning also has weaknesses, according to (Bullen, 2001; Beam, 1997), the weaknesses of learning through the internet include a lack of interaction between teachers and students or even between students themselves which can cause the declining achievement. Mustakim's research results (2020) concluded that most high school students stated that online learning was very effective and effective in learning mathematics.

This problem also occurs in the State Vocational High School 3, Bengkulu Utara district, the implementation of online learning is found weaknesses, among others, teachers are still not used to teaching using online media, so learning becomes less effective, teachers do not prepare material properly, limited good facilities from the teacher and students, the cost of quotas and internet network disruptions, the burden on teachers is large, the burden of students on assignments given by the teacher with a short time limit, even complaints about the burden of parents having to become teachers for their children at home, and must help with the assignments given the teacher. Practical learning also experiences difficulties, because practical learning requires children and teachers to interact to see examples directly.

Based on these problems, this study aims to describe the principal's planning in preparing for the implementation of online learning, the implementation of online learning, the supervision carried out by the principal in monitoring the implementation of online learning, the obstacles encountered in implementing online learning and solutions to overcome obstacles in school online learning. Intermediate Vocational State Bengkulu Utara.

\section{METHODS}

This research was conducted using a descriptive method with a qualitative approach and literature study. Qualitative research is used by referring to the opinion of Sugiyono (2009), that the qualitative research method is a naturalistic research method because the research is carried out in natural conditions (natural setting), and the data collected is analyzed qualitatively. Qualitative is considered relevant to describe the current conditions and 
becomes the background for research, namely online learning during a pandemic. (Creswell \& Poth, 2016). (Lewis, 2015).

Data collection was carried out by offline and online interviews, documentation, research subjects, principals, teachers, and students. Miles and Hubermen (2014) argued that activities in qualitative data analysis were carried out interactively and continued to completion so that the data was saturated. The measure of data saturation is indicated by no longer obtaining new data or information. Activities in the analysis include data reduction, data display, and conclusion drawing or verification.

\section{RESULT AND DISCUSSION}

a. Preparations were carried out by the principal in following up on online learning during the Covid-19 pandemic. First, by holding coordination meetings with teachers to discuss online learning plans. The meeting agenda discusses and provides direction, motivation to teachers in facing online learning so that teachers are psychologically prepared and prepare lesson plans with this new system.

The principal makes a policy by making technical decisions for the implementation of online learning that will be carried out by the teacher, including forming an online learning task force team, teacher pickets, teachers preparing material in the form of books, power points, youtube, assignments to be carried out by students, online implementation time schedules for each. fields of study and preparing facilities such as computers, other means that support and are needed by teachers in preparing material and student assignments.

After the preparation has been understood by the teacher, the next step is to notify students by letter through parents about the implementation of online learning during the Covid 19 pandemic. This is to prepare parents and students both psychologically and physically for changes in the learning system.

b. The implementation of online learning was initially carried out simply considering the condition of the teacher, the facilities owned by the school, and the conditions of the existing facilities for the students. The form of implementing online learning is carried out at the beginning once a week the teacher provides material and assignments that must be studied by students and assignments that must be done by students. After one week, students turn in assignments by coming to school and taking materials and assignments again for the next week.

As time went on, the next form of learning with the development of the COVID-19 pandemic and considering that the location of Vocational High School 3 Bengkulu Utara was in a green zone area, the implementation of learning was carried out in a variety of ways according to recommendations from the Education Ministry. There are still studies that use online and offline. Face-to-face activities while still applying the covid 
protocol, namely face-to-face learning between teachers and students in the class. This face-to-face implementation is carried out alternately for each class with a set of 15 students per class with seats spaced according to covid19 prevention standards. This offline learning is carried out with a meeting time duration of one hour and changes with the next class

c. Supervision and monitoring of the implementation of online learning at Vocational High School 3 Bengkulu Utara Regency is carried out by the principal in monitoring the implementation of online learning. The principal and deputy principal in the curriculum sector monitor and supervise the implementation of online learning carried out by the teacher by looking at the schedule implementation report, the attendance list of students who come to take assignments and submit assignments, conducting regular meetings to get reports from the teacher on the implementation and obstacles encountered in implementing online learning. This supervision is carried out to monitor the implementation of learning and can immediately overcome if some obstacles or problems occur both in terms of teachers and students so that learning objectives can still be achieved.

The task force is in charge of monitoring whether each subject teacher has prepared assignments for students and whether each student has worked on and deposited them to the school, it can be seen from the administration of records in the book that the picket teacher has prepared. The flow of these activities is recorded to facilitate supervision so that if there are teachers whose learning activities have not been fulfilled, their learning activities can be immediately reminded to immediately carry out unresolved tasks.

d. Obstacles that seem to be experienced include some teachers who cannot still design teaching materials/materials in the form of online, for example making YouTube learning materials, power points, giving challenging assignments so they tend to rely on student control books, lack of interaction with students causing students to not understand the material, only photocopies of material from the book. curriculum targets are difficult to achieve, practical learning is difficult to implement.

While the obstacles from the students themselves decreased learning motivation, decreased students' ability to understand the material, especially in Science, Mathematics and English subjects, lack of discipline in submitting assignments, the lack of student interaction with the teacher made many students have difficulty understanding the subject matter and the opportunity to ask questions. teachers are very limited, students are less disciplined in submitting assignments, there is interference with the internet network because students' homes are far from schools, the cost of pulses for students. 
e. Solutions to overcome obstacles that exist in online learning. The principal conducts a policy of conducting workshops to improve teacher skills in online learning, facilitating teachers to carry out peer tutoring by preparing a room with a computer they own to practice together preparing teaching materials in the form of power points, YouTube, student worksheets, student assignments, so that teachers can discuss and For teachers who do not understand how to use computers, they can study with their peers, do offline learning in one class twice ship with a maximum number of students with a maximum of 15 people with a duration of 1-hour meeting.

While the solution from the teacher to improve students' understanding of the learning material is done by forming a group with students to make it easier to give directions, clarify the tasks being carried out, as well as a place for students to ask the teacher if there are obstacles in doing the assignments. Bring in resource persons to train teachers to make online-based assessments, create learning.

Online learning carried out at North Bengkulu Regency Vocational High School 3 has generally been implemented by the signs and provisions of the North Bengkulu Education National Education Office, initially full online learning was carried out by giving assignments to students once a week, then along with the development of learning carried out offline or face-to-face but still maintaining the protocol for the spread of covid19 by keeping a distance, wearing masks, and a short meeting period of 1 hour/meeting with a limited number of students in one class of 15 people.

However, the online learning that was carried out during the Covid19 pandemic seemed sudden, rushed due to the coercive circumstances, resulting in teachers and students not being ready to psychologically run online models. Such conditions certainly hurt both teachers and students and even student achievement. According to Naserly, M. K., (2020), the use of online learning using zoom cloud meetings has the advantage of being able to interact directly between students and lecturers as well as teaching materials but it has the disadvantage of being wasteful and less effective if there are more than 20 students. In addition, the challenges of online learning are the availability of internet services, constraints in the financing, parents, and students complaining that to take part in online learning, they have to pay quite a fortune to buy internet data quotas.

Pangondian, R. A., Santosa, P. I., \& Nugroho, E. (2019) stated that there are many advantages to the use of information and communication technology in the implementation of online learning, among them are that they are not bound by space and time. However, online learning using the internet for middle students needs to be watched out for because it is feared that they will not pay attention during learning due to playing on social media and the entry of misleading information (Siddiqui \& Singh, 2016). 
The main obstacle felt by teachers and students in online learning is the unstable internet network, especially those in the regions, so that it interferes with the learning process and in doing and sending student assignments. This is by the results of research Hendrastomo's (2008) research results that the availability of internet access is needed in e-learning learning because the characteristics of this learning always use and utilize the internet network. In general, the speed of internet network access in Indonesia is relatively slow, the availability of the internet network is still limited and the price for accessing the internet is relatively expensive, thus becoming obstacles to e-learning learning.

\section{CONCLUSION}

Preparation for online learning by the principal by holding a coordination meeting with the teacher: forming a task force, discussing implementation techniques, determining the schedule, delivering notification letters to student guardians, conducting workshops for teachers on online learning techniques, preparing facilities for teachers who support online learning

The implementation of online learning is carried out with various variations considering the conditions of the facilities owned by the school and the conditions of existing facilities for students. The form of implementing online learning is carried out at the beginning by once a week the teacher provides material that must be studied by students and assignments that must be done by students, sends learning you, wahatsup. Furthermore, by taking turns faceto-face for each class by arranging for each class as many as 15 students with seats set at a distance with a meeting time duration of one hour while still applying the Covid protocol.

Supervision and monitoring of online learning are carried out by the principal and task force. The instruments used are picket book lists and schedule implementation reports, attendance lists of students who come to take assignments and submit assignments, conduct routine meetings, and curriculum materials.

The obstacles to the implementation of online learning at Vocational High School 3 Bengkulu Utara Regency are first in terms of teachers, the lack of teacher ability in designing teaching materials / online materials such as making learning youtube, PowerPoint, google classroom. Meanwhile, the obstacles from students are lack of motivation to learn, lack of discipline in submitting assignments, lack of understanding of the material, credit financing borne by parents, internet networks.

Solutions made by principals and teachers in overcoming obstacles in online learning include: implementing in-house training online learning strategies, preparing computer facilities in schools to practice together preparing teaching materials in the form of power points, youtube, student worksheets, student assignments. Doing offline learning in one class twice ship with a duration of 1-hour meeting. 


\section{REFERENCE}

Allan J. Henderson. 2003. The E-learning Question and Answer Book. USA: Amacom.

Arikunto, Suharsimi. 2002. Metodologi Penelitian. Penerbit PT. Rineka Cipta. Jakarta.

Beam, P.1997. Breaking the Sprinter's Wrist: Achieving Cost-Effectiveness in Online Learning.

Bullen, M. 2001. e-Learning and the Internationalization Education. Malaysian Journal of Educational Technology 1(1)

Creswell, J. W., \& Poth, C. N. (2016). Qualitative inquiry and research design: Choosing among five approaches. Sage publications.

Efendy, Onong Uchana. 2005. Ilmu Komunikasi Teori dan Praktek. Bandung:Remaja Rosda Karya.

Eko Kuntarto, 2017. Keefektifan Model Pembelajaran Daring Dalam Perkuliahan Bahasa Indonesia Di Perguruan Tinggi. Jurnal, IJEIL. Vol 3.No. 1. ISSN online: 2502-2261.

Emmilia Rusdiana, Arianto Nugroho. 2020. Judul Penelitian Respon Mahasisa Pada Pembelajaran Daring Bagi Mahasisa Mata Kuliah Pengantar Hukum Indonesia UNESA Journal Integralistik Universitas Negeri Semarang, ISSN 0853- 7208, Vol 31, No 1

Fauzi, I., \& Khusuma, I. H. S. (2020). Teachers' elementary school in online learning of COVID-19 pandemic conditions. Jurnal lara': Kajian Ilmu Pendidikan, 5(1), 58-70.

Hikmah Mu'alimah dan Ishafit.2017. Pembelajaran inkuiri kolaboratif daring dengan media social Whats App pada kemampuan komunikasi terhadap materi kalor bagi peserta didik di abad 21. Proseding Seminar Nasional Fisika.http://ejournal.ikippgrimadiun.ac,id/indek.php/snpf. ISSN : 2527-6670,

Kaler, C. B. (2012). A model of successful adaptation to online learning for college-bound Native American high school students. Multicultural Education \& Technology Journal.

Kemendikbud - Dirjen GTK, 2016. Guru Pembelajar - Petunjuk Teknis Moda Dalam Jaringan (Daring).

Kementerian Pendidikan dan Kebudayaan RI.2014. Panduan Pengembangan dan Penyelenggaraan KDITT, Jakarta: Kemendikbud.

Lewis, S. (2015). Qualitative inquiry and research design: Choosing among five approaches. Health promotion practice, 16(4), 473-475.

Miles,M.B, Huberman,A.M, dan Saldana,J. 2014. Qualitative Data Analysis, A Methods Sourcebook, Edition 3. USA: Sage Publications. Terjemahan Tjetjep Rohindi Rohidi, UIPress.

Mustakim (2020). Efektivitas Pembelajaran Daring Menggunakan Media Online Selama Pandemi Covid-19 Pada Mata Pelajaran Matematika. Journal of Islamic Education, al asma, ISSN 2715-2812 (Online) Vol. 2, No. 1, May 2020.

Naserly, M. K. (2020). Implementasi Zoom, Google Classroom, Dan Whatsapp Group Dalam Mendukung Pembelajaran Daring (Online) Pada Mata Kuliah Bahasa Inggris Lanjut 
(Studi Kasus Pada 2 Kelas Semester 2, Jurusan Administrasi Bisnis, Fakultas Ekonomi Dan Bisnis, Universitas Bina Sa. Aksara Public, 4(2)

Pangondian, R. A., Santosa, P. I., \& Nugroho, E. (2019). Faktor-Faktor Yang Mempengaruhi Kesuksesan Pembelajaran Daring Dalam Revolusi Industri 4.0. In Seminar Nasional Teknologi Komputer \& Sains (SAINTEKS) (Vol. 1, No. 1).

Picciano, A. G., Seaman, J., Shea, P., \& Swan, K. (2012). Examining the extent and nature of online learning in American K-12 education: The research initiatives of the Alfred P. Sloan Foundation. The internet and higher education, 15(2), 127-135.

Priyadarshini, A., \& Bhaumik, R. (2020). E-readiness of Senior School Learners to Online Learning Transition amid COVID-19 Lockdown. Asian Journal of Distance Education, 15(1), 244256.

Sadiq, K. (2020). Communities of practice as a multidisciplinary response in times of crisis: adapting to successful online learning practices. Accounting Research Journal.

Samruayruen, B., Enriquez, J., Natakuatoong, O., \& Samruayruen, K. (2013). Self-regulated learning: A key of a successful learner in online learning environments in Thailand. Journal of Educational Computing Research, 48(1), 45-69.

Siddiqui, S., \& Singh, T. (2016). Social Media its Impact with Positive and Negative Aspects. International Journal of Computer Applications Technology and Research. https://doi.org/10.7753/ijcatr0502.1006

Sugiyono. 2016. Metode Penelitian Pendidikan, Pendekatan Kuantitatif, Kualitatif, dan R\&D. Bandung: Alfabeta.

Watson, J. (2008). Blended Learning: The Convergence of Online and Face-to-Face Education. Promising Practices in Online Learning. North American Council for Online Learning.

Yudiawan, A., \& Sunarso, B. (2021). Successful Online Learning Factors in COVID-19 Era: Study of Islamic Higher Education in West Papua, Indonesia. International Journal of Evaluation and Research in Education, 10(1), 193-201. 